\title{
2019 ESC GUIDELINES FOR THE DIAGNOSIS AND MANAGEMENT OF ACUTE PULMONARY EMBOLISM: HABEMUS (NOVAM) LEX!
}

\author{
Antoniu Octavian Petriş ${ }^{1,2}$ \\ "Grigore T. Popa" University of Medicine and Pharmacy, Iaşi \\ "st. Spiridon"County Emergency Hospital, Iaşi
}

\begin{abstract}
Current Guidelines for the diagnosis and management of acute pulmonary embolism (PE), as well as all other Guidelines, summarize and evaluate the already available evidence and consensus "with the aim of assisting health professionals in proposing the best management strategies for an individual patient with a given condition".

In this review we present the most important new recommendations of the latest ESC Guidelines on the diagnosis and management of acute pulmonary embolism.
\end{abstract}

Keywords: acute pulmonary embolism, ESC Guidelines.

\begin{abstract}
Ghidurile actuale pentru diagnosticul și managementul embolismului pulmonar acut (PE), similar celorlalte ghiduri, rezumă și evaluează dovezile disponibile, ca și consensul expecerților, „cu scopul de a ajuta profesioniștii din domeniul sănătății în stabilirea strategiei optime de management pentru un pacient cu o patologie dată".

În această lucrare vă prezentăm cele mai importante recomandări ale Ghidurilor ESC recente privind diagnosticul și managementul embolismului pulmonar acut.
\end{abstract}

Cuvinte cheie: embolism pulmonar acut, ghiduri ESC.

We used to expect that the medical practice Guidelines, especially in cardiology, occur within a reasonable amount of time (usually five years), being the result of the intense work of a collective of representative members of the highest scientific guild, as it is the European Society of Cardiology, moving from "clinical judgment" and "art of medicine" field (the traditional approach to making decisions about individual patients based solely on the opinion of the attending physician) to "evidence-based medicine" (approach intended to optimize decisionmaking by emphasizing the use of evidence from well-designed and well-conducted research), as it was developed by Gordon Guyatt in the autumn of 1990 at McMaster University $^{(1)}$. W.V. Quine describes the 


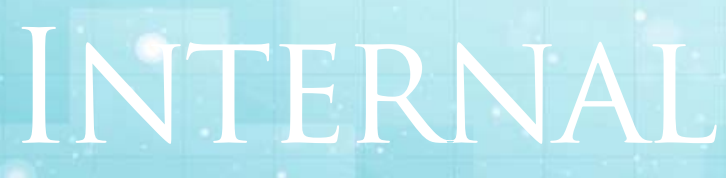

General Reviews

evidence-based medicine, in a philosophical analysis, as a spider web (a web of belief), that has an exterior edge or frame, and an interior consisting of rays and vertices ${ }^{(2)}$. Current Guidelines for the diagnosis and management of acute pulmonary embolism (PE), as well as all other Guidelines, summarize and evaluate the already available evidence and consensus "with the aim of assisting health professionals in proposing the best management strategies for an individual patient with a given condition" and the same health professionals are encouraged "to take the ESC Guidelines fully into account when exercising their clinical judgment in consideration of each patient's health condition and in consultation with that patient and the patient's caregiver where appropriate and/or necessary" ${ }^{(3)}$.It is about the judicious use of all the available resources with the intention of doing good but taking into account the wishes of the one who is the subject of our therapeutic act who must be well informed but also held responsible to assume its part of responsibility in this endeavor.

Here is a list with the most important new recommendations that, from my point of view, the latest ESC Guidelines on the diagnosis and management of PE brings to us.

First of all, rescue thrombolytic therapy is recommended for patients with PE who deteriorate haemodynamically (statement that has progressed from class of recommendation Ila to class I, based on the accumulated evidence but also on what already dictates our daily clinician common sense). The delay to administrate thrombolytic therapy or the decision-making "stuttering", just looking for the moment when the patient meet all the "classical" criteria of high-risk and hemodynamically worsening PE will result in increasing mortality determined by the initiation of the spiral of hemodynamic instability and their progression to the "unstoppable" cardiac arrest $^{(4)}$.

Secondly, 2019 ESC Guidelines state, with class of recommendation Ila B for edoxaban and Ila $C$ for rivaroxaban, that each of these two NOACs (or, better said, direct oral anticoagulants - DOACs) should be considered as an alternative to LowMolecular Weight Heparin (LMWH), with a word of caution for patients with gastrointestinal cancer due to the increased bleeding risk in this cluster ${ }^{(3)}$.

The ongoing Caravaggio study will assess whether oral apixaban is non-inferior to subcutaneous LMWH dalteparin for the treatment of newly diagnosed proximal deep venous thrombosis (DVT) and/or pulmonary embolism (PE) in patients with cancer and will probably put apixaban on the list of anticoagulants that can be administered to 
cancer patients ${ }^{(5)}$.For patients with $\mathrm{PE}$ and cancer, extended anticoagulation (beyond the first 6 months) should be considered for an indefinite period or until the cancer is cured, the Guidelines say ${ }^{(6)}$.

Thirdly, therapeutic anticoagulation must be administered for 3 months (understood as a minimum length of time) to all patients with PE (class of recommendation I) and potential indications for extended anticoagulation are discussed, terminology such as provoked vs unprovoked PE/VTE no longer being accepted by the Guidelines, as potentially misleading notion, not helpful for decisionmaking regarding the duration of anticoagulation.

A reduced dose of apixaban (2.5 mg b.i.d.) or rivaroxaban (10 mg o.d.) should be considered after the first 6 months of treatment of PE patients (class of recommendation Ila). More than that, indefinite treatment with a Vitamin $\mathrm{K}$ Antagonist (VKA) is recommended for patients with antiphospholipid antibody syndrome (class of recommendation I) ${ }^{(3)}$.

Fourthly, assessment of the right ventricle by imaging or laboratory biomarkers should be considered, even in the presence of a low Pulmonary Embolism Severity Index (PESI) or a SPESI of 0 (class of recommendation Ila) $)^{(3)}$. Occurrence of right ventricular dysfunction in the context of pulmonary embolism is already well demonstrated being correlated with the survival of these patients. In some cases (thrombus-in-transit or a "saddle" thrombus stopped at the bifurcation of the pulmonary artery) signs of threats may initially not be expressed but, when the progression of the embolus to the pulmonary circulation continues, dramatic consequences may occur.

Fifth, set-up of multidisciplinary teams (PERT) for management of high-risk and selected cases of intermediate-risk PE should be considered, depending on the resources and expertise available in each hospital (class of recommendation Ila). The optimal structure of a PERT remains unknown (emergency medicine, interventional and noninterventional cardiology, cardiac surgery and hematology but probably also vascular medicine and surgery or pharmacy), each member having a crucial role in this institutionally based multidisciplinary team that must meet at least the following criteria:

1. ability to rapidly assess and provide treatment for patients with acute pulmonary embolism;

2. a formal mechanism to exercise a full range of medical, surgical, and endovascular therapies;

3. provide appropriate multidisciplinary follow-up of patients;

4. if feasible, willingness to collect, evaluate, and share data regarding the effectiveness of treatment rendered $^{(7)}$.

For the first time mentioned in a version of PE Guidelines, ExtraCorporeal Membrane Oxygenation (ECMO), a technology largely derived from cardiopulmonary bypass, may be considered (in combination with surgical embolectomy or catheter-directed treatment) in refractory circulatory collapse or cardiac arrest(3).

Habemus papam ("We have a pope") is the announcement traditionally given by the Protodeacon of the College of Cardinals or by the senior cardinal deacon participating in the papal conclave, in Latin, upon the election of a new pope of the Catholic Church, the white smoke billowing from the Sistine Chapel in the Vatican indicating that the voting members of the College of Cardinals have chosen new pontiff. Habemus (novam) 


\section{INTERNAL}

\section{General Reviews}

lex is an exclamation of satisfaction that we periodically expres following an increasingly anxious expectation that the results of valuable trials must be reflected as quickly as possible in guidelines and that this guidelines also be implemented as quickly as possible in our daily medical practice.

\section{References}

1. Guyatt GH. Evidence-based medicine. ACP J Club 1991; 114: A16.

2. Sehon SR, Stanley DE. A philosophical analysis of the evidence-based medicine debate. BMC Health Services Research 2003; 3: 14.

3. Konstantinides SV, Meyer G, Becattini C et al. 2019 ESC Guidelines for the diagnosis and management of acute pulmonary embolism developed in collaboration with the European Respiratory Society (ERS) The Task
Force for the diagnosis and management of acute pulmonary embolism of the European Society of Cardiology (ESC). Eur Heart J 2019; 00: 161 doi:10.1093/eurheartj/ehz405.

4. Beydilli i, Yılmaz F, Sönmez BM, et al. Thrombolytic therapy delay is independent predictor of mortality in acute pulmonary embolism at emergency service. KaohsiungJ Med Sci 2016; b32 (11): b572-578.

5. Agnelli G, Becattini C, Bauersachs $R$, et al. Apixaban versus dalteparin for the treatment of acute venous thromboembolism in patients with cancer: The Caravaggio Study. Thromb Haemost 2018; 118(9): 1668-1678.

6. Napolitano M, Saccullo G, Malato A, et al. Optimal duration of low molecular weight heparin for the treatment of cancer-related deep vein thrombosis: the Cancer-DACUS Study.J Clin Oncol 2014; 32: 3607-3612.

7. Rosovsky R, Borges J, Kabrhel C, Rosenfield K. Pulmonary embolism response team: inpatient structure, outpatient follow-up, and is it the current standard of care? Clin Chest Med 2018; 39: 62130. 